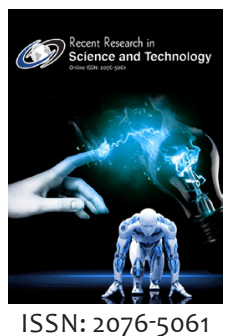

Received: March 23, 2020 Revised: June 19, 2020 Accepted: June 20, 2020 Published: June 29, 2020

*Corresponding Author: Md. Sajjat Hossain E-mail: : sajjathossainbrur@ gmail.com

\section{Exploring the knowledge of social media platforms among higher education institute students' of Rangpur, Bangladesh}

\author{
Md. Tabiur Rahman Prodhan, Md. Nazrul Islam, PhD, Md. Sajjat Hossain* \\ Department of Mass Communication and Journalism, Begum Rokeya University, Rangpur (Bangladesh)
}

\begin{abstract}
Social media (SM) is one of the best indicators of the technological era. Nowadays people are witnessing the rapid increase of SM in almost every field of our lives from education to politics, society, and economics. It attracts all ages of people. Especially students show an intense interest in social media. The purpose of the study was to know the most preferred SM and the using pattern knowledgeability of respondents regarding various social media platforms (SMPs). A questionnaire-based survey was conducted over 100 students (60 males and 40 females) who were selected randomly from two higher education institutes in Rangpur, northern part of Bangladesh, studying in undergraduate and postgraduate programs in 2019 between ages 18 and 26. $95 \%$ of the respondents used different social media platforms where the top preferred social media platforms are Facebook (88\%), YouTube (81\%), and IMO (45\%). The mean values of the respondents' using pattern knowledgeability level were between 4.46 and 1.88 , with standard deviations ranging from 1.10 to 1.83 . Most of the respondents have enough using pattern knowledgeability of being a user of Facebook with a wide range of mean scores in both the variables. Respondents have less using pattern knowledgeability of being a user of Viber with a tight range of mean scores in both the variables. All the dependent variables (features), except one (r-value 0.253), showed positive and significant correlations with the usage period where both the features of Twitter have the highest positive significance ( $\mathrm{r}$-value $0.945,0.941$ respectively). These scores were significant at $\mathrm{p}<0.05$ level of probability.
\end{abstract}

KEYWORDS: Social media platform, feature, knowledge

Abbreviations: SM- Social Media, SMPs- Social Media Platforms, BRUR- Begum Rokeya University, Rangpur, AMAC- Abuja Municipal Area Council

\section{INTRODUCTION}

Social media are platforms that facilitate electronic conversation. "No clear, accepted definition of social media is available" [1]. Kaplan and Haenlein suggested that social media are "a group of internet-based applications that build on the ideological and technological foundations of Web 2.0, that allow User Generated Content to be created and exchanged" [2].

Approximately 3.8 billion people are social media users, delivering 49 percent of global penetration [3]; for example, if Facebook is a country it would be regarded as the world's third largest population-based country, besides China and India [4]. The use of social media is evolving swiftly. For example, looking at the short history of Twitter, one can see the number of tweets went from 5,000 tweets per day in 2007 to 500 million tweets per day in 2013 and 600 million tweets per day in 2020 [5].
Students at universities find social media convenient as they are able to use them at their desired time and place and they fulfill various needs. Most students, nowadays, use social media to keep themselves socially active $[6,7]$.

For several reasons, students enjoy social media. Firstly, social networks offer a sense of freedom to do whatever they want to post and speak to whoever they want. They can find new friends and comment on the post inbox by them. Social media has provided students a place where they can generate virtual communities that may generate conflicts in the real world. With more liberty, it provides them the freedom to fascinate themselves. It was simply impossible for young attentions to create an electronic appearance of their activities through such an unprompted medium just a decade before [8]. 
Moreover, communication through social networks and other online public forums can be beneficial for them, both socially and professionally only when carried out sensibly and securely. Therefore, it can be argued that students must have exact knowledge of each of the existing features of social media sites. However, if those features are not taken into consideration seriously, it can lead to numerous undesirable consequences like cyberstalking. So research needs to be plotted to know the using pattern knowledgeability of various social media sites they used. However, researchers are already involved in research works using different parameters to figure out various aspects concerning social media usage by students.

Alfaris et al. stated that of the medical students who responded to their research, among them $98 \%$ were the user of different social media platforms where the most popular social media platforms were WhatsApp (87.8\%), YouTube $(60.8 \%)$, and Twitter (51.8\%). They also mentioned that $83.5 \%, 35.5 \%$ \& $35.3 \%$ of the subjects used YouTube, WhatsApp, and Twitter for learning purposes respectively [9].

Otunomeruke \& Sunday had researched the social media networks, knowledge, attitude, and practice and its effects on academic performance among secondary school students using a cross-sectional survey among Government Secondary School, Lugbe, Abuja Municipal Area Council (AMAC). Findings of the study showed that the majority of the students have adequate knowledge, positive attitude, and regularly visit social media networking sites. Researchers found that $27.9 \%$ of the students are currently using Facebook, 21\% uses WhatsApp and Google each, YouTube users (12\%), Blackberry Messenger (9\%), and others $(9 \%)[10]$.

A study conducted in 2010 found that $1 \%$ of students did not have any knowledge about Facebook while 29\%, 31\% \& 39\% had somewhat a little knowledge, vast knowledge, and enough knowledge respectively. The study also showed that $25 \%$ of students did not have any knowledge about Twitter while $45 \%$ $\& 8 \%$ had somewhat a little knowledge, and vast knowledge respectively. Morely, the study revealed that $2 \%$ of students did not have any knowledge about Youtube while 16\%, 41\% \& 41\% had somewhat a little knowledge, vast knowledge, and enough knowledge respectively [11].

Hence, this study aimed to assess the respondents' most preferred social media platforms, and each feature knowledgeability level. Until now, such type of research has not been conducted by any of the researchers in Bangladesh and so this study is aimed for future reference. Therefore, more research needs to be done to expand the existing methods to a broader range of analytes.

\section{METHODS}

In the empirical part of this study, a quantitative approach was employed using a structured questionnaire among 100 students (60 males and 40 females) of two higher education institutes in Rangpur, northern part of Bangladesh studying in undergraduate and postgraduate programs in 2019 between ages 18 and 26 .
Quantitative research was used rather than qualitative because quantitative methodology is appropriate to collect a large amount of data and statistically appropriate to prove the broad generalities of the study, face-to-face contact between the researchers and participants was employed to avoid human bias whenever possible. Researchers used a structured questionnaire. The questionnaire was prepared in Bangla with keeping in mind the respondents' mother language and there were no foreign students of these institutions. Random multi-stage sampling was used. In each institute, 50 students were selected by simple random sampling. A pilot test was conducted on 33 students to confirm the reliability of the questionnaire and Cronbach's alpha value was computed as 0.7930 . The questionnaire was based on respondents' most preferred social media platforms, each feature knowledgeability and included demographic characteristics including age, sex, marital status, and level of education. After obtaining the necessary coordination and obtaining permission from both institutions' authority, the research team was referred to the selected institutions, and the questionnaire distributed among eligible subjects after taking informed consent. Participants' consent was taken as per rules and the study objectives, pros, and cons of the study were discussed with the participants. Statistical analyses of the quantitative and qualitative data were performed using the SPSS software and an observed correlation from -1 to +1 would be considered statistically significant at the $\mathrm{P}=0.05$ level (2-sided).

\section{RESULTS \& DISCUSSION}

\section{Demographic Information of the Respondent}

This study collected the student demographic information regarding their gender, age, marital status, and level of education to find out if these variables would affect student perceptions and attitudes towards the use of social media platforms.

Demographic characteristics of the participants are shown in Table 1. On the whole, there were 100 students in the study population, with ages from 18 to 26 . Among them, $40 \%$ were female students, $6 \%$ were married, and $82 \%$ were undergraduate students.

Tablel: Demographic characteristics of study population

\begin{tabular}{lcc}
\hline Characteristics & \multicolumn{2}{c}{ Overall $(\mathrm{N}=100)$} \\
\cline { 2 - 3 } & No. & $(\%)$ \\
\hline Sex & & 60 \\
Male & 60 & 40 \\
Female & 40 & \\
Age group (yrs) & & 33 \\
18-20 & 33 & 30 \\
$21-22$ & 30 & 27 \\
$23-24$ & 27 & 10 \\
$25-26$ & 10 & 6 \\
Marital status & & 94 \\
Married & 6 & 82 \\
Unmarried & 94 & 18 \\
Education level & & \\
Undergraduate & 82 & \\
Postgraduate & 18 &
\end{tabular}

Recent Res Sci Technol • $2020 \quad$ • Vol 12 


\section{Usage of Social Media Platforms}

Among respondents, $95 \%$ of students said they use social media platforms and rest of others are not. Students who responded, 88\% were Facebook users, $81 \%$ were YouTube users, 28\% were WhatsApp users, $45 \%$ were IMO users, $12 \%$ were Viber users, $35 \%$ were Twitter users, $21 \%$ were LinkedIn users, and $5 \%$ were all platform users. A study conducted in 2010 found that $90 \%$ of university students drawn from one hundred twenty-six US and Canadian universities use social networking websites [12]. Saha and Guha found that of the 502 students $63.7 \%, 19.5 \%$, 9.3\%, and $7.3 \%$ were Facebook, YouTube, Instagram, and Twitter users respectively [13]. The simultaneous accounts of various social media resonate well with Lenhartetal."'s study [14]. They reported that more than half of social network users had a personal profile on multiple social media platforms.

This study also investigated respondents' minimum usage period of social media platforms (Table 2). Respondents who were the users of Facebook among them 24\% said that they were the users for the past 4 years respectively. $22 \%$ and $17 \%$ told that they were the users for the past 6 years and 7 years respectively and $12 \%$ said that they were not the users. In this study, respondents who were the users of Twitter among them, $11 \%$ were the users for the past 4 years and $65 \%$ said that they were not the users. Respondents who were the users of YouTube among them, 23\% said that they were the users for the past 7 years and 19\% said that they are not the users. $79 \%$ and $72 \%$ of respondents said that they were not the users of LinkedIn and WhatsApp respectively. Respondents who were the users of IMO among them, $17 \%$ said that they were the users for the past 2 years and $55 \%$ said that they were not the users. Most of the respondents (88\%) were not the users of Viber.

\section{Using Pattern Knowledgeability of Respondents about Various Social Media Platforms}

Researchers divided each of the social media platform features into two types (Table 3). For measuring the using pattern knowledgeability level, the data has been collected by using a '5'

Table 2: Usage period of social media platforms

\begin{tabular}{|c|c|c|c|c|c|c|c|}
\hline Usage period (yrs) & Facebook(\%) & Twitter(\%) & LinkedIn(\%) & YouTube(\%) & WhatsApp(\%) & IM0(\%) & Viber(\%) \\
\hline One & 2 & 1 & 2 & 0 & 5 & 13 & 2 \\
\hline Two & 4 & 2 & 2 & 4 & 3 & 17 & 5 \\
\hline Three & 5 & 3 & 6 & 17 & 7 & 12 & 1 \\
\hline Four & 24 & 11 & 2 & 9 & 6 & 3 & 4 \\
\hline Five & 14 & 8 & 1 & 12 & 2 & 0 & 0 \\
\hline Six & 22 & 4 & 3 & 16 & 4 & 0 & 0 \\
\hline Seven & 17 & 6 & 5 & 23 & 1 & 0 & 0 \\
\hline Not a user & 12 & 65 & 79 & 19 & 72 & 55 & 88 \\
\hline
\end{tabular}

Table 3: Mean, standard deviation (SD), variance, and standard error (SE) for each of the types of variables (features) of seven social media platforms

\begin{tabular}{|c|c|c|c|c|c|}
\hline $\begin{array}{l}\text { Social media } \\
\text { platforms }\end{array}$ & Variables (Features) & Mean & $\begin{array}{l}\text { Standard } \\
\text { deviation }\end{array}$ & Variance & $\begin{array}{l}\text { Standarc } \\
\text { error }\end{array}$ \\
\hline \multirow[t]{2}{*}{ Facebook } & General: create an account, add profile details, create group(s)/ page(s)/ event(s). & 4.25 & 1.19 & 1.42 & 0.12 \\
\hline & $\begin{array}{l}\text { Additional: change password, lock profile, like(s)/ comment(s), share stories, go live on } \\
\text { Facebook, download a video, follow/ unfollow people, login/logout, upload/ sharea picture or } \\
\text { video, change privacy settings, add/ edit/ delete/ hide post(s), tagging, upload cover photo(s), } \\
\text { upload profile picture(s). }\end{array}$ & 4.46 & 1.14 & 1.30 & 0.15 \\
\hline \multirow[t]{2}{*}{ Twitter } & General: create an account, customize profile, create own List(s). & 2.51 & 1.40 & 1.95 & 0.11 \\
\hline & $\begin{array}{l}\text { Additional: post photo(s) or GIF(s), share/ watch video(s), post links(s), create live video(s)/ } \\
\text { poll(s), upload and organize video(s), like/ comment on a tweet, download video(s), see } \\
\text { notification(s), follow/ unfollow people, change password, delete Tweet(s), log in/log out. }\end{array}$ & 2.61 & 1.51 & 2.28 & 0.12 \\
\hline \multirow[t]{2}{*}{ LinkedIn } & General: create an account, add profile detail(s), create group. & 2.12 & 1.26 & 1.58 & 0.13 \\
\hline & $\begin{array}{l}\text { Additional: adding or changing background photo(s), share video(s), live streaming, join } \\
\text { group(s), like/ commenton post(s), see notification(s), change password, delete post(s), login/ } \\
\text { logout. }\end{array}$ & 2.20 & 1.39 & 1.9 & 0.14 \\
\hline \multirow[t]{2}{*}{ YouTube } & $\begin{array}{l}\text { General: create a channel, create \& manage playlists, create a video group, customize channel } \\
\text { layout, upload/ replace/ delete video(s), live streaming, sign in/sign out. }\end{array}$ & 2 & 1.42 & 2.02 & 0.14 \\
\hline & $\begin{array}{l}\text { Additional: like(s)/ comment(s), download video(s), share video(s) in other platforms, search } \\
\text { video(s), see notification(s), subscribe to channel(s). }\end{array}$ & 4.25 & 1.32 & 1.74 & 0.13 \\
\hline \multirow[t]{2}{*}{ WhatsApp } & General: installing app, create an account, create \& invite into group(s). & 2.21 & 1.39 & 1.95 & 0.14 \\
\hline & $\begin{array}{l}\text { Additional: send text(s)/ picture(s)/ voice message(s)/video(s), voice and video call(s), } \\
\text { document sharing, delete message(s). }\end{array}$ & 2.39 & 1.61 & 2.62 & 0.16 \\
\hline \multirow[t]{2}{*}{ IMO } & General: installing app, create an account, create a chat group & 2.85 & 1.71 & 2.94 & 0.17 \\
\hline & $\begin{array}{l}\text { Additional: photo(s)/ video(s) sharing, send text(s)/ voice message(s), audio/ video call(s), } \\
\text { deleting all text chat history. }\end{array}$ & 3.02 & 1.83 & 3.37 & 0.18 \\
\hline \multirow[t]{2}{*}{ Viber } & General: installing app, create an account, create chat group(s). & 1.88 & 1.10 & 1.22 & 0.11 \\
\hline & $\begin{array}{l}\text { Additional: send text(s), photo(s)/GIF(s)/ video(s)/voice message(s)/ file(s), audio/ video } \\
\text { call(s), hide/ delete chat. }\end{array}$ & 1.93 & 1.21 & 1.46 & 0.12 \\
\hline
\end{tabular}


point Likert scale where scales range from 1 to 5 . As shown, the mean values of the respondents' using pattern knowledgeability level were between 4.46 and 1.88, with standard deviations ranging from 1.10 to 1.83 . Table 3 showed that most of the respondents have enough using pattern knowledgeability of being a user of Facebook with a wide range of mean scores in both the variables. Respondents have less using pattern knowledgeability of being a user of Viber with a tight range of mean scores in both the variables.

\section{Correlation between Respondents' using Pattern Knowledgeability Level and Usage Period}

Respondents'usage period of social media platforms included as an independent variable while using pattern knowledgeability level used as a dependent variable. To test the hypothesis concerning the relationship between the independent and dependent variables Pearson product-moment correlation coefficient (r) has been computed (Table 4). Five percent (0.05) level of probability was used as the basis for acceptance or rejection of the research hypothesis. The hypothesis only shows a significant relationship when ' $r$ ' value was significant at $\mathrm{p}<0.05$ level of probability.

All the dependent variables (features), except one (r-value 0.253), showed positive and significant correlations with the usage period. Table 4 exposes that both the features of Twitter have the highest positive significance ( $\mathrm{r}$-value $0.945,0.941$ respectively).

Table 4: Pearson correlation coefficient ( $r$ ) between respondents' using pattern knowledgeability level and usage period

\begin{tabular}{|c|c|c|}
\hline Dependent Variables (Features) & Independent Variable & 'r' Values \\
\hline $\begin{array}{l}\text { Using pattern knowledgeability } \\
\text { level of Facebook (General) }\end{array}$ & Usage period & $0.789 * *$ \\
\hline $\begin{array}{l}\text { Using pattern knowledgeability } \\
\text { level of Facebook (Additional) }\end{array}$ & & $0.825 * *$ \\
\hline $\begin{array}{l}\text { Using pattern knowledgeability } \\
\text { level of Twitter (General) }\end{array}$ & & $0.945 * *$ \\
\hline $\begin{array}{l}\text { Using pattern knowledgeability } \\
\text { level of Twitter (Additional) }\end{array}$ & & $0.941 * *$ \\
\hline $\begin{array}{l}\text { Using pattern knowledgeability } \\
\text { level of LinkedIn (General) }\end{array}$ & & $0.759 * *$ \\
\hline $\begin{array}{l}\text { Using pattern knowledgeability } \\
\text { level of LinkedIn (Additional) }\end{array}$ & & $0.791^{* *}$ \\
\hline $\begin{array}{l}\text { Using pattern knowledgeability } \\
\text { level of YouTube (General) }\end{array}$ & & $0.253^{\mathrm{NS}}$ \\
\hline $\begin{array}{l}\text { Using pattern knowledgeability } \\
\text { level of YouTube (Additional) }\end{array}$ & & $0.777^{* *}$ \\
\hline $\begin{array}{l}\text { Using pattern knowledgeability } \\
\text { level of WhatsApp (General) }\end{array}$ & & $0.808 * *$ \\
\hline $\begin{array}{l}\text { Using pattern knowledgeability } \\
\text { level of WhatsApp (Additional) }\end{array}$ & & $0.851 * *$ \\
\hline $\begin{array}{l}\text { Using pattern knowledgeability } \\
\text { level of IMO (General) }\end{array}$ & & $0.829 * *$ \\
\hline $\begin{array}{l}\text { Using pattern knowledgeability } \\
\text { level of IMO (Additional) }\end{array}$ & & $0.849 * *$ \\
\hline $\begin{array}{l}\text { Using pattern knowledgeability } \\
\text { level of Viber (General) }\end{array}$ & & $0.766^{* *}$ \\
\hline $\begin{array}{l}\text { Using pattern knowledgeability } \\
\text { level of Viber (Additional) }\end{array}$ & & $0.821^{* *}$ \\
\hline
\end{tabular}

** Correlation is significant at $p<0.05$ level of probability (2-tailed).

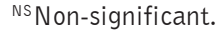

\section{CONCLUSION}

With the fast advancement of technology, there will be more cutting-edge technologies appearing in that market daily. As a researcher, should we ignore them or chase after them? It is always a huge challenge to keep up with new technology trends. No matter how fascinating a new technology can become, it is still a tool. Technology can not replace us but can assist in human interactions, and enhance our daily life experiences.

The emerging social media tools that we investigated and discussed in the paper are existing resources among students. Students feel relaxed with the tools that they already know. Although, smart use of social media tools can engage students in interactive learning, which is the key to a successful education. Thus social media tools should need to be used for learning purposes. While using for learning purposes, educators need to train students and equip them with analytical and deep thinking skills to make the best use of it.

Future researches need to be approached to determine how students are spending their time on social media sites each time they login or sign in. Apart from literate people, the nonliterate peoples are also using social media sites in those days. So, to know how non-literate peoples are using social media sites, research needs to be assigned and even incorporating the ethnic minority groups of Bangladesh will also add value as illiteracy rates are high among them [15-17].

\section{SOURCE OF FINANCIAL SUPPORT}

There is no funding to be disclosed.

\section{CONFLICT OF INTEREST}

The authors declare that they have no competing interests.

\section{REFERENCES}

1. Scott PR, Jacka JM. Auditing social media: A governance and risk guide. John Wiley \& Sons; 2011 Feb 25.

2. Kaplan AM, Haenlein M. Users of the world, unite! The challenges and opportunities of Social Media. Business horizons. 2010 Jan 1;53(1):59-68.

3. We are social. Digital in 2016. Available from: https://wearesocial. com/blog/2020/01/digital-2020-3-8-billion-people-use-social-media (accessed on 20 June 2020).

4. The economist. Facebook population: status update. Available from: https://www.economist.com/news/2010/07/22/statusupdate (accessed on 03 May 2020).

5. Twitter. Twitter Usage Statistics. Available from: http://www. internetlivestats.com/twitter-statistics/ (accessed on 20 June 2016).

6. Lenhart A, Madden M, Macgill AR, Smith AW. Teens and social media: The use of social media gains a greater foothold in teen life as they embrace the conversational nature of interactive online media. Washington, DC: Pew Internet \& American Life Project; 2007 Dec 19.

7. Knight-McCord J, Cleary D, Grant N, Herron A, Lacey T, Livingston T, Emanuel R. What social media sites do college students use most. Journal of Undergraduate Ethnic Minority Psychology. 2016;2(21):21-6

8. TECNICIAN. The impact of social media on student life. Available from: http://www.technicianonline.com/opinion/article_d1142b70- 
5a92-11e5-86b4-cb7c98a6e45f.html (accessed on 3 May 2020).

9. AlFaris E, Irfan F, Ponnamperuma G, Jamal A, Van der Vleuten C, Al Maflehi N, Al-Qeas S, Alenezi A, Alrowaished M, Alsalman R, Ahmed AM. The pattern of social media use and its association with academic performance among medical students. Medical teacher. 2018 Jul 6;40(sup1):S77-82.

10. Otunomeruke JA, Sunday J. A Study of Social Media Networks' Knowledge, Attitude and Practice and Its Effects on Academic Performance among Secondary School Students, Abuja, Nigeria. International Journal for Social Studies. 2017;03(05): 01-12.

11. Liu Y. Social media tools as a learning resource. Journal of Educational Technology Development and Exchange (JETDE). 2010;3(1):8.

12. Smith S, Caruso J, Kim J. ECAR Study of Undergraduate Students and Information Technology, 2010. EDUCAUSE Center for Analysis and Research (ECAR). [Online] 2010; ECAR Research Study 6: 1-120. Available from: https://library.educause.edu/ resources/2010/10/ecar-study-of-undergraduate-students-andinformation-technology-2010 (accessed on 02 April 2020).
13. Saha SR, Guha AK. Impact of Social Media Use of University Students. International Journal of Statistics and Applications. 2019;9(1): 36-43. doi:10.5923/j.statistics.20190901.05.

14. Lenhart A, Purcell L, Smith A, Zickuhr K. Social media and young adults. Pew Internet and American Life Project. Retrieved June 20, 2011.

15. Masud Ahmed S. Differing health and health-seeking behaviour: ethnic minorities of the Chittagong Hill Tracts, Bangladesh. Asia pacific journal of public health. $2001 \mathrm{Jul} ; 13(2): 100-8$.

16. Lasker MS, Dio LM, Chowdhury MH, Hossain MS, Islam MN, Chowdhury MJ. Lifestyle of the Nomadic River Gypsies and their Threat Narrative: A Tale of Two Villages in Bangladesh. International Journal of Environmental Sciences \& Natural Resources. 2019;17(5):154-61

17. Akan MR, Al Mamun MA, Naznin T, Al Pavel MA, Yasmin L, Rahman SA. An ethnographic investigation on land and life of Santal community in Barind Tract, Bangladesh. American Journal of Social Science Research. 2015;1(2):90-5. 